16 Жапов В. Bbl говорите по-черному? “Иностранеч” 2002 Coоn // Cambridge Advanced Learner's Dictionary \& Thesaurus -книга

\title{
References:
}

1 Paşkova E.A. İazykovye i sosiokülturnye osobenosti pesennogo diskursa (na materiale ruskogo $i$ angliskogo iazykov). Nauchnye tendensii: Filologia, Külturologia, İskustvovedenie, 2016 M. c. 6-12-stätä

2 Baranov A.N. Protiv "razlojenia smysla": uznavanie v semantike idiom. Kömpüternaia lingvistika $i$ intelektuälnye tehnologii. Vyp. 7 (14). Po materialam mejdunarodnoi konferensii Dialog 2008. M., 2008. c. 39-44. stätä

3 Karipjanova G. T., Abikenov M. T.Skript, freim, shema v hudojestvennom tekste. Gumanitarnyi vektor. Seria: Filologia, vostokovedenie 2016, Vypusk 3, s.105-110 - stätä

4 Morrison T. The Bluest Eye M.2017 - kniga

5 Psihiatricheski ensiklopedicheski slovär (Stoimenov I.A., Stoimenova M.I., Koeva P.I. i dr., Kiev: MAUP, 2003, 1200 str.) - slovär

6 Walker A. The Color Purple., London: Orion Publishing Group, 2014 - kniga

7 Sebrük A.N. Antroponimicheskie reprezentanty afroamerikanskogo soobşestva $v$ amerikanskom variante angliskogo iazyka. Rhema. Rema 2013., c.62-67. - stätä

8 Sapphire "Push", 1996, 181 pp. - kniga

9 Morrison T. Beloved http://www.6lib.ru/books/Beloved-198932.html - internet-istochnik

10 Nigger https://www.dictionary.com/browse/nigger-internet-istochnik

11 Aleksandrova T. A. Spesifika rechevogo povedenia predstavitelei afroamerikanskogo sosiälno-etnicheskogo dialekta angliskogo iazyka. İvestia Saratovskogo universiteta. Filologia. Jurnalistika. 2018. T. 18, vyp. 2, c. 145-148stätä

12 Morrison T. Song of Solomon, 1977 - kniga

13 Morrison T. God Help the Child, 2015 - kniga

14 Bollen Ch. Toni Morrison's Haunting Resonance // Interview Magazine, May 1, 2012 - kniga

15 Aleksandrova T. A. Spesifika vyrajenia osenochnyh znacheni v afro-amerikanskom sosiälno-etnicheskom dialekte: na materiale substandartnoi leksiki, avtoreferat diser...kand.filol.nauk., Saratov, 2007, 23 s. - disertasia

16 Japov V. Vy govorite po-chernomu? “Inostranes” 2002 Coon // Cambridge Advanced Learner's Dictionary \& Thesaurus -kniga

\section{МРНТИ 16.31.51}

\author{
Мейірманова Г.С., ${ }^{1}$ Кенжевұлова Ф.К. ${ }^{2}$ \\ ${ }^{1,2}$ М.Х.Дулати атындавы Тараз өңірлік университеті, \\ Тараз, Қазақстан
}

\section{МӘТІН СИНТАКСИСІНДЕГІ БАЙЛАНЫСТЫРУШЫ КҰРАЛДАР}

Аңцатпа

Мақаланың негізгі мақсаты қазақ тіліндегі мәтін синтаксисін және ондағы байланыстырушы құралдарды анықтау болып табылады. Жұмыста дейксис, анафора, катафора сияқты ұғымдардың тіл білімі тарихында зерттелуіне тоқтала отыра, мәтін синтаксисіндегі байланыстырушы құралдар сараланады. Жұмыста мәтінді байланыстырушы дейксистік, анафоралық, катафоралық байланыс құралдары сөз болады. Аталған мәтінді байланыстырушы құралдардың қолданысына қазақ жазушыларының шығармаларынан мысалдар келтірілген. Тілдік материалдар негізінде мәтін синтаксисіндегі дейксистік байланыс құралдары нақты мысалдармен анықталып, дәлелденеді. Мәтін ішіндегі анафоралық байланыс құралдарының түр-түрі анықталады. Сондай-ақ мәтін синтаксисіндегі катафоралық байланыс құралдары да сарапқа салынған. Сілтеу есімдіктерінің сөзді, сөз тіркестерін, сөйлем мүшелерін, предикаттарды, сөйлемдерді, синтаксистік тұтастықтарды, сілтей отыра мәтіндерді байланыстыратын тілдік құралдар рет-ретімен дәлелді мысалдарымен анықталады.

Түйін сөздер: мәтін, анафора, дейксис, субститут, катафора, антецедент, референт

$$
\begin{gathered}
\text { Meirmanova } G .,{ }^{1} \text { Kenzhegulova } F^{2} \\
{ }^{1,2} \text { Taraz Regional University named after M.H. Dulati, } \\
\text { Taraz, Kazakhstan }
\end{gathered}
$$




\title{
TOOLS LINKING IN THE SYNTAX OF THE TEXT
}

\begin{abstract}
The main purpose of the article is to determine the syntax of the text in the Kazakh language and the means connecting it. The paper explores such concepts as deixis, anaphora, cataphora in the history of linguistics, differentiates the connecting means in the syntax of the text. The work uses deixic, anaphoric, and cataphoric means of communication that connect the text. Examples of the use of means of linking this text from the works of Kazakh writers are given. On the basis of linguistic material taksikuskit means of communication in the syntax of the text are defined and demonstrated with concrete examples. The type of anaphoric means of communication within the text is determined. The means of cataphoric communication in the text syntax were also analyzed. The language means that connect words, phrases, sentence members, predicates, sentences, syntactic integrity, reference texts are determined by consecutive reasoned examples.
\end{abstract}

Keywords: text, anaphora, deixis, substitute, cataphora, antecedent, referent

$$
\begin{gathered}
\text { Мейрманова Г.С., }{ }^{1} \text { Кенжегулова Ф. К. }{ }^{2} \\
{ }^{1,2} \text { Таразский региональный университет им. М. Х. Дулати, } \\
\text { Тараз, Казахстан }
\end{gathered}
$$

\section{ИНСТРУМЕНТЫ СВЯЗЫВАНИЯ В СИНТАКСИСЕ ТЕКСТА}

\section{Аннотация}

Основной целью статьи является определение синтаксиса текста на казахском языке и связующих в нем средств. В работе исследуются такие понятия, как дейксис, анафора, катафора в истории языкознания, дифференцируются связующие средства в синтаксисе текста. В работе используются дейксические, анафорические, катафорические средства связи, связывающие текст. Приведены примеры использования средств связывания данного текста из произведений казахских писателей. На основе языкового материала дейксические средства связи в синтаксисе текста определяются и доказываются конкретными примерами. Определяется вид анафорических средств связи внутри текста. Также были проанализированы средства катафорической связи в синтаксисе текста. Языковые средства, связывающие слова, словосочетания, члены предложения, сказуемые, предложения, синтаксические целостности, ссылочные тексты определяются последовательными аргументированными примерами.

Ключевые слова: текст, анафора, дейксис, субститут, катафора, анттецедент, референт

Кіріспе. Мақалада мәтін лингвистикасына қатысты мәселелер сөз болады. Мәтін лингвистикасы аясында мәтінге тән негізгі жағдайлар, мәтіннің маңызы мен негізділігі, басқа тілдік фактілерден өзгешелігі, мәтіннің кұрылу заңдылықтары, оған тән категориялар, мәтінде бейнеленген объективті шындық, мәтіннің түзілуінің тілдік ерекшелігі, мәтіндегі тұлғалар және оларды байланыстырушы тілдік құралдар және т.б. мәселелер қарастырылады. Қазіргі қазақ тіл білімінде мәтін лингвистикасын зерттеудің маңызы артып отырғаны мәлім. Сол себепті мәтін синтаксисіндегі байланыстырушы құралдарды анықтау бүгінгі таңда өзекті болып табылады.

Мәтін лингвистикасы - тіл білімінің бір саласы. Лингвистиканың бұл саласының негізі Г.Лакофф, Р.Харвег, В.Скаличка, Ә.Бенвенист, С.Карцевский, З.Шмидт, Т.Николаева және т.б. еңбектерінде қаланған десек те болады. Орыс тіл білімінде мәтінтану мәселесіне А.С.Рейсер, Б.В.Томашевский, Д.С.Лихачев, Г.О.Винокур, П.Н.Берков, Е.И.Прохоров т.б. зерттеушілер өз үлестерін қосқаны белгілі.

Жоғарыда аталған ғалымдардың еңбектерінің негізінде қазақ тіл білімінде де мәтін лингвистикасының барлық ұғымдары мен негізі, ондағы қолданылатын терминдер қалыптасқан.

Қазақ тіл білімінде Р.Сыздықтың "Қазақ тіліндегі ескіліктер мен жаңалықтар" атты еңбегі 2009 жылы жарыққа шықты. Бұл - мәтін лингвистикасы саласына қосылған тың еңбектің бірі еді. Бұл еңбегінде Р.Сыздық апайымыз мәтін лингвистикасына қатысты қазақ тіл біліміндегі бірнеше мәселелерді анықтаған:

- біріншіден, текстологиялық зерттеулерді жетілдіру қажеттігіне;

- мәтінге жеткілікті дәрежеде көңіл бөлінуіне;

- тарихи мәтіндерге;

- кейінгі жаңа жазба мәтіндерді де жариялану барысында кемшіліктердің жіберілуіне;

- мәтіндердің көне мен ескіліктердің топтастырылған орны, қазынасы екендігіне;

- ескілер мен көнеліктердің мән-мағынасын ашу кезінде мәтіндердің көмегіне жүгінуге көп көңіл бөлінген.

Сондай-ақ, мәтіннің негізгі ерекшеліктері туралы қазақ тіл білімінде кең көлемді еңбек жазған Г.Смағұлова сынды ғалымды атап өтсек болады [2]. Сонымен қатар, 3.Ахметованың мәтін лингвистикасы саласында жазған еңбегінің де айтарлықтай орны бар [3].

Мәтінді байланыстырушы құралдар дегенде біз көбінесе есімдіктерді еске аламыз. Бұл есімдіктердің синтаксистік жүйедегі қызметін олардың сілтеу функциясы белгілейді десек, осы сілтеу функциясымен бірге орынбасу субституция, дейксис, эгоцентризм, анафора, катафора ұғымдары анықталмақ. 
Есімдіктердің дейксистік, эгоцентристік, анафоралық, катафоралық қызмет ерекшеліктері ерте кезден бастап-ақ сөз болуда. "Дейксис" терминінің өзі грек тілінен аударғанда "сілтеу" деген мағынаны береді. Антикалық заманның грамматистері Дионисий Фракийский, Аполлоний Дисколдардың еңбектерінде сілтеу есімдіктері "дейксис" терминімен белгіленген. Сол антикалық заманнан бері сөз болған есімдіктер одан келе батыс ғалымдарының еңбектеріне арқау болды. Есімдіктердің лингвистикадағы қызметін белгілеуде ғалымдар түрлі ұғымдар енгізді. Мәселен, есімдіктердің орынбасарлық қызметін Г.Суит алғаш сөз етсе, субституция теориясын Л.Блумфильд бастап, Р.Гарверг жалғастырады және де бұл мәселеге Р.Краймз 1965 жылы докторлық диссертациясын арнайды. Ал дейксис теориясын сөз еткен К.Бругманның ой-пікірлері К.Бюлердің еңбектерінде (1934) жалғастырылып, К.Бюлердің бұл ойлары кейін келе "эгоцентризм" теориясына бастау болды.

Жалпы "дейксис" ұғымына тіл білімі тарихында әр ғалым өзіндік анықтамалар беріп кеткен. Мәселен, К.Бюлер бойынша дейксистік сөздер - қатынас ситуациясында мағыналық толықтыруға ие бола отыра көрінген затқа сілтеуді іске асыратын сөздер болса, бұл туралы осы мәселені көп зерттеген орыс ғалымы Н.Д.Арутюнова былай дейді: "Дейктические слова, своего рода "подвижные определители" приложимые к любому референту" $[4,42]$.

Тоқсаныншы жылдары есімдіктердің синтаксистік жүйедегі қолданыс ерекшеліктерін ашуға септігін тигізген үлкен еңбектің бірі - А.Кравченконың "Вопросы теории указательности: эгоцентричность, дейктичность, индексальность" (1992) атты еңбегі [5].

Соңғы жылдары да бұл тақырып тоқырап, тоқтап қалған жоқ. Түркология тарихында кейінгі жылдарда да диссертациялық еңбек жазған авторлар өте көп. Оның ішінде К.А.Бейсембаеваның (2002) - "Невербальные компоненты коммуникации в казахском языке" [6] атты еңбегі ерекше құнды дей аламыз.

Қазақ тілін зерттеу мәселесі қолға алынғаннан бері есімдіктерді зерттеуге көптеген ғалымдар атсалысты, олардың мақалалары мен зерттеу еңбектерінде, есімдіктер түрлі қырларынан сөз болды. Ол қатарға мына еңбектерді жатқызуға болады: Н. Сауранбаевтың «Есімдіктер», Ш.Сарыбаевтың "О местоимениях ту, түнеу", "К вопросу о местоимении в казахском языке" [7], А.Төлеуовтің "Қазақ тіліндегі есімдіктер", А.Ысқақовтың "Есімдіктер", А.Ибатовтың "Қазақ тіліндегі есімдіктер тарихынан", "Қазақ тіліндегі есімдіктер" атты еңбектері.

Есімдіктердің функционалды синтаксистегі қызметтері соңғы жылдардағы зерттеулерде қарала бастады. Профессор Р.Әмірдің еңбектерінде сілтеу есімдіктерінің анафористік қызметтері сөз болады [8]. Н.Құрманованың 2001 жылғы "Қазіргі қазақ тіліндегі сөз тіркестерінің жүйелік құрылымының сипаты, оны талдау жолдары" атты еңбегінде сілтеу есімдіктерінің сөз тіркестерінің қатарында жұмсалуы, олардың өзге сөз таптарымен тіркесу қабілеттері сөз болады [9].

Есімдіктердің мәтінді байланыстырушы қызметіне келсек, олардың бұл қызметі сілтеу мағыналарынан келіп шығады Бұл есімдіктердің мәтіндегі қызметін олардың сілтеу функциясы белгілейді десек, осы сілтеу функциясымен бірге орынбасу субституция, дейксис, эгоцентризм, анафора, катафора ұғымдары анықталмақ. Сондықтан, біріншіден, осы ұғымдарды саралап, олардың тіл біліміндегі қолданыстарын, ғалымдардың ойпікірлерін қарастырамыз.

Әдістеме. Мәтінді байланыстырушы құралдардың алғашқысы - дейксистік есімдіктер. Ал дейксис теориясына келетін болсақ, лингвистика тарихында есімдіктердің дейксистігі туралы ерте кездерден бастап айтылған. Алайда ол кездегі дейксис ұғымы қазіргі дейксис ұғымымен сай келмейді. Ол кездегі дейксис ұғымына жалпы есімдіктердің сілтеу мағынасын беруі сәйкес келген. "Дейксис" ұғымын кең және тар көлемде пайдалану олардың түрліше түсіндірілуіне негіз болады. Кең көлемде дейксис зат, белгі, жағдай тағы басқаларға ситуациялық немесе контекстік сілтеуді қамтиды, ал тар көлемде бір функцияны айтады және екі элементті қамтиды: дейксистік белгі мен оның референті.

Енді біз жіктеу есімдіктерінің дейксистік, эгоцентристік қызметін саралаймыз. Есімдіктердің мағыналары жалпы болғандықтан, олардың қызмет ерекшеліктері де жалпы және жан-жақты болады. Олардың негізгі мазмұнын олардың мағыналары емес, қызметі анықтайды. Бұл туралы А.В. Исаченконың есімдіктерге синтаксистік тұрғыдан қарау керек деген ойын біз жоғарыда келтірдік.

Мәселен:

- Тұрар, сен бүгін өзгешелеусің вой өзін.

- Мен сенің алдыңда кіндлімін, Әзизаш (Ш.Мұртаза).

Бұл жерде алғашқы қолданыстағы "сен" - Әзизаға, ал екінші қолданыстағы "мен" - Тұрарға тән, яғни әр жіктеу есімдігінің өз референциялары бар, олар бір-бір индвидке сәйкес келіп тұр.

II жақ сен есімдігін толық түсіндіру үшін адресат, тыңдаушы ұғымдарының екеуін де қамтитын сөйлеу объектісі терминін қолдану керек. Сонда жіктеу есімдіктері жоғарыда көрсеткеніміздей, "мен - сөйлеу субъектісі", "сен - сөйлеу объектісі", "ол - сөйлеу заты" болып табылады.

"Мен", "сен" есімдіктері кейіптеу кезінде жансыз заттарға да тән болып келе береді. Көбінесе поэзиялық шығармаларда, ертегілердегі жан-жануарлардың сөйлесуінде олар дейксистік (тура сілтеу) қолданысқа түсе алады. Мысалы,

- Мен сені қ̧азір босатамын, бірақ менің ауруымның емін тауып келмесең, сені өлім күтеді, - дейді ашуль арыстан түлкіге ызылана қъарап. 
Сен, мұнда, осында, онда, сонда сөздерінің бәрін де анықтағанда «мен» қолданылады. Олардың мәні сөйлеушінің субъективті еркімен белгіленеді, олар сөйлеушіден тыс бола алмайды. Сонда олар былай анықталады:

"мен" - сөйлеп тұрған адам; "сен" - мен сөйлеп тұрған адам; "ол" - мен де, сен де емес, бөгде жан; "мұнда" мен тұрған жер; "онда" - мен жоқ жер.

Осылай, мұндай, сондай, солай, осылайша сөздері тура сілтеуді іске асыра отыра, үнемі баяндауыш мүшемен қабыса байланысып, пысықтауыш қызметінде жұмсалады. Мысалы, Кейде айшықты сөз длдеқайда алыстан кеп, осылай таңырққатып та кетуі керек (М.Әуезов).

Сілтеу есімдіктерінің қатарындағы мына, ана, сона, мынау, анау, сонау есімдіктері де өз дәрежелерінде тура сілтеуді іске асырады. Мысалы, Ойбай-ау, мына жұрт не дейді, Бақа!? (М.Әуезов).

Анау, мынау, сонау есімдіктері уақыттық кезеңдерді білдіре отыра, дейксистік (тура сілтеу) қолданыста жұмсалады. Мысалы, Анау жұмадавы хұтпадан кейін болван құақтывыс жайы аржақ пен бержақтыңң барлық жаназаларында, хатімінде, жетілерде қулың сөз болып, барлық қалага тарап жатты (М. Әуезов).

Осы сілтеу ұғымымен байланысты тағы бір байланыс құралы - анафоралық есімдіктер. "Анафора" (айтылғанды сілтеу) болып табылады. Оны біз "айтылғанды сілтеу" деп шартты түрде атадық. Бір сөздің мағынасында екінші бір сөзге деген сілтеуі бар болатын тілдік сөйлесімдердің қарым-қатынасы анафоралық (айтылғанды сілтеу) қатынас болып табылады.

Бұл элементтердің арасында синтаксистік байланыс жеткіліксіз болғанда анафоралық (айтылғанды сілтеу) элементтер бірінші планға шығады. Мысалы, Үйдің імі құараңзъы және тыл-тырыс еді. Онда от жоқ (Ш.Айтматов).

Мұнда "онда" деген анафоралы сілтеу "үйдің іші" деген антецедентті ауыстырады. Анафоралық қатынастағы ауыстырылатын сөз - антецедент, есімдікпен берілетін элемент - анафора болып табылады.

Егер сөз, сөз тіркесі, сөйлемдерді ауыстырып тұратын III жақ формалары болмаса, сөйлесім мен коммуникацияның жүзеге асуы өте қиын болар еді.

Себебі автор сөзі пікір алысушының білімін құрайтын мәліметтерді айтады. Мысалы, Ол сынып оқушыларын мұвалімдер бөлмесіндегі жылап тұрган қыздың қ̧асына алыл келіп, былай деді: "Егер сендер тавы да мына қыызда тиісетін болсаңдар, мектептен шыгасыңдар".

Мұндағы мына қыз деген мұzалімдер бөлмесіндегі жылап тұрzан қыззда қатысты. Бұл автор сөзінен түсінікті болып тұр, яғни анафора көрініс беруде. Ал диалогтың өз ішінде жағдайдың элементі - дейксис көрініп тұр. Анафора - контекстің өзі, дейксис сөйлеу актісінің ситуациясы.

Біз енді сондай анафоралық қатынастар мен анафораның түрлерінде сілтеу есімдіктерінің жұмсалу ерекшеліктерін сөз етпекпіз.

Мәселен: Бұл кітап қ̧ызық.. Осыны тауысып тастасаққ қ̧айтеді (Ә.Нұршайыққов); (анафора). Сен мынаны ұқ̧: біз бұл жерден қ̧алайда көшуіміз керек (Д.Исабеков) (катафора).

Сөйлеу актілерінің күнделікті қолданысында анафора мен оның антецеденті мәтінмен енгізіліп отырады, сондықтан да анафора мәтіндегі екі белгінің - анафоралық (айтылғанды сілтеу) көрініс пен антецеденттің арасындағы байланыстарды көрсетеді. Сілтеу есімдіктері анафоралық қолданыста жұмсалғанда, олардың антецеденттері әртүрлі болып келеді. Сонымен қатар мәтінде анафораға қарама-қарсы жағдай да орын алады. Мысалы, Айтыл, түсіндіріп кеткені мынау: ревизорва құваздарды көрсетпей-ақ, мәселені оңынан шешуіміз керек (Д.Исабеков).

Мұнда анафоралы "мынау" есімдігі екінші компонентті, яғни антецедентті түгелдей сілтеп, өзі бірінші жұмсалып тұр, міне, мұны катафора дейміз, яғни бірінші анафоралы есімдік жұмсалады да, сосын барып антецедент айтылады. Катафораны шартты түрде "алдын алушы" деп қолданамыз. Біз жұмысымызда анафора терминін де тар мағынасында, яғни бірінші компонентті, алдындағыны сілтеу мағынасында қолданамыз. Есімдіктердің анафоралылығын сөз еткенде, біз өзіндік анафора мен катафора ұғымдарын қолданып, жіктеу, сілтеу есімдіктерінің осындай қызметін саралаймыз. Анафора көрініс беріп қойған ақпаратты қайталап жатпау үшін, яғни сөз үнемдеу үшін пайдалынылса, дейксис тілде ақпаратты тура сілтей отыра атау үшін, оны сөйлеу ситуациясынан даралап алу үшін қажет.

Катафора - мәтінді байланыстыруда үлкен орын алады. Мәселен: Мына мәселеге басты назар салу керек: оқушылардың тәртібі төмендеп кеткен, тіпті, сабақ уақытысының өзінде жасалван тәртіпсіздіктер

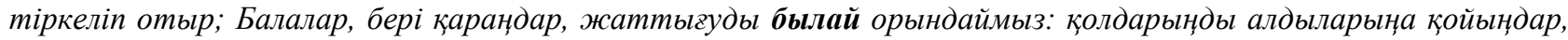
екі аяқтарыңды иық бойында ұстаңцдар да, бір- екі деп отырып, тұрыңдар.

Негізінде сілтеу есімдіктері бастапқы қолданысында мәтінді бастамайды, ал катафоралық (алдын алушы) қолданысында ол мәтіннің басында тұрса, онда соңындағы бір затты көрсетуге, соған назар аудартуға қажеттілік туындайды. Ал кейде мұндай қолданыс стилистикалық тәсіл ретінде жұмсалады. Mblcaлbl, Coл бip жайма шуақ көктем келгенде ауыл жайлаува көшіп, бәріміз тіршілігімізге кірісіп, Асыл да қэаладан келіп қуанып құлган едік.

Кейде зат есім жекеше формада келіп, сілтеу есімдіктерінің сапалық мағынасы предикатпен негізделеді. Мысалы, Мынадай жауап дайын тұратын: Мен шетелге шығып, сауда жасавалы отырмын. Бүгін-ертең виза дайын болмак,

Антецеденті сөйлемнің жалғасы болып келетін катафоралы сілтеу есімдікті құрылымдарда оқиғаға баға берушілік сипаты болады. Мысалы, Мен осы ақымақтықты жасадымм, тады да ажырастылм. 
Мәселен: Сіздердің мыналарыңыз, тіпті де, ақымақ емес, ол бәрін де біліп істеп отыр. Мұнда тіпті де ақымақ емес деген антецедент предикатив позициясында қолданылып тұр, ал егер субъект позициясында қолданылса (тіпті де ақымақ емес айтты), онда сөйлесімнің құрылымы бұзылады, ол субъект позициясында жұмсала алмайды.

Катафоралық (алдын алушы) қызметте мына, ocы, сол, ол сілтеу есімдіктері жұмсала алады. Олардың ішінде ең көп қолданысқа түсетіні - мына есімдігі: Бие сауымдай кеңесіп, үлкендер құауымының шешкені мынау болды: Табын көшіне енді бұл арада қалува болмайды (I. Есенберлин).

Сондай-ақ, осындай, сондай, осылай, былай есімдіктері де катафоралық (алдын алушы) қолданыста жұмсалады. Мысалы, Алты алашқ̧а аян осындай кім бар: құазақтыңң құолын бастап, басын құосып, жауына құарсы тұрар; Аттың сыны да, сыры да сондай болмақ̆: ерге қ̧анат болар, жауынан аман альлп қ̧айтар, мұнайганда сырласар (І.Есенберлин);

Сонымен бірге сілтеу есімдіктері сөйлеу актісінің номинативтік және коммуникативтік аспектілерімен байланысты белгілерді көрсетуге мүмкіндік беретін сөйлесім аспектілерін саралау құралының қызметін атқарады.

Нәтижелер. Жалпы дейксис есім сөздер мен есімдіктерді жақындастырады, есімдер затты атауды, оның адам санасында белгілі бір ұғым қалыптастыруын көрсетсе, есімдіктер өзінің заттық мағынасымен ауыспалы дейксистік (тура сілтеу) байланыста болады.

"Дейксис" (тура сілтеу) термині ретінде түрлі тілдік құралдардың сілтеуіштік қызметімен байланысты кең көлемдегі тілдік құбылыстар түсініледі. Ол ең, біріншіден, сілтеу түрлерін анықтайды (жақ, орын, мезгіл т.б.), сосын сілтеушінің, сөйлеу ситуациясының есеп беру нүктесін анықтайды да, сілтеуді жүзеге асырады. Осы сөйлеуші фигурасына қатысты "мен-сен" есімдіктері және осы сөйлеушіге қатысты анықталатын «мұнда, сонда, онда» сөздері, сөйлеу ситуациясына қатысты ocbl, бұл, сол есімдіктері, есеп беру нүктесі арқылы анықталатын осында, мұнда, міне, әне сөздері эгоцентристік болады, яғни олар белгілі бір "сөйлеуші - "мен" центризміне" қатысты сілтеуді іске асырады. Сонымен, сөйлеуші барлығын өз көзқарасы тұрғысынан айтып, бәрін өзі басқарғанда, сөйлеу ситуациясындағы сілтеу эгоиентристік болады.

Есімдіктердің орынбасарлық қызметі бұрыннан-ақ белгілі, сол сияқты олар дейксистік, анафоралық қызметте де жұмсалады екен. Жіктеу есімдіктерінің ішіндегі мен, сен есімдіктері ақпарат бере алмайды, өйткені мен, сен сөздерін белгілейтін объекті жоқ, бұлар үнемі сөйлеу сәтімен байланысты болады. Әрбір "меннің" де, "сеннің" де өз референциялары болады, олар әр кезде де жеке бір ғана индивидке сәйкес келеді.

Анафоралық сілтеу сол сөйлеу актісін өзіндегідей референті бар келесі бір сөйлеу актісіне қатыстыра байланыстырады және де үш элементтің арақатынасына құрылады: екі тілдік белгі (оның біреуі дейксистік) мен референтті (екі мағынаны да қамтитын референт) қамтиды. Сондықтан да тіл білімінде анафораны көбінесе конферентті сілтеу деп атап жүр.

Анафоралық (айтылғанды сілтеу) қатынастарды қарастыруда антецедент, қайталау, анафора, катафора, ретроспективті, проспективті анафора, субститут, орынбасу, субстанционалды, концептуалды, дискурсивті анафора деген ұғымдар мен анафораның түрлері ажыратылады.

Анафора да тіл білімінде дейксис тәрізді кең және тар мағынасында жұмсалады. Кең мағынасында ол жалпы мәтіндегі сөздердің бәрін көрсететін болса, тар мағынасында ол тек алдыңғы контекстегі, сөйлемдегі элементтерді сілтеуді іске асырады да, анафора (айтылғанды сілтеу) және катафора (алдын алушы) деген анафораның екі түрін ажыратады немесе анафораның бұл екі түрін біз ретроспективті және проспективті анафора те деп атаймыз, біз өз жұмысымызда анафора (айтылғанды сілтеу) және катафора (алдын алушы) деген атауды қолдануды жөн көрдік.

Сілтеу есімдіктері анафоралық (айтылғанды сілтеу) қолданыста кеңінен жұмсалып, мәтін, сөйлем элементтерін байланыстырады және де мәтіндегі керексіз қайталауларды ауыстырады. Бұл қызметінде олар өзіндік анафоралық (айтылғанды сілтеу) та, катафоралық (алдын алушы) та қолданыстарда жұмсалады. Есімдіктердің бұл қызметі мәтін синтаксисінде кеңінен орын алады.

Катафоралық (алдын алушы) сілтеулер көбінесе бір нәрсе жайын ұзақ түсіндіруде, көрсетуде жұмсалады. Автор өзі айтатын, өзі орындатқысы келетін нәрселерге тыңдаушылардың назар салып қарау қажеттігін ескерткісі келгенде көбіне сілтеу есімдіктерін катафоралы қолданады.

Катафоралық (алдын алушы) қолданыстағы сілтеу есімдіктерінің мағыналары белгісіз болады, олар соңғы сөйлемдер арқылы нақтыланады. Бұл мәтінге дейінгі, сөйлеуші мен тыңдаушы үшін ортақ ұсынылатын жүйе элеметтерін көрсетеді. Сілтеу есімдіктері басқа мәтіннің жасырын цитаталарын көрсетуші, соны жалпы ұғымға енгізуші элемент ретінде жұмсалады.

Сілтеу есімдіктері анафоралық қолданыста қосымша мағынаға ие болмаса, өз қызметінде артық болса, ол эллипсистеніп, нөлдік анафора көрініс бере алады. Анафоралық және катафоралық қолданыстарда сілтеу есімдіктерінің жұмсалыстарына түрлі факторлардың қарым-қатынастары, жалпы мәтіннің семантикалық сипаттары және де экстралингвистикалық факторлар әсер етеді.

Талқылау. Жалпы "дейксис" ұғымына тіл білімі тарихында әр ғалым өзіндік анықтамалар беріп кеткен. Дейксистік (тура сілтеу) құралдары жоқ ұзақ сөйлесімдер келесі адамға мүлде түсініксіз болуы мүмкін. Дейксистік (тура сілтеу) есімдіктер референцияның негізгі құралдары болып табылады. Дейксис коммуникативтік актідегі конситуцияны алып тастауға болатын ақпаратты атау үшін қолданылады. Олар 
мынадай түрлерге бөлінеді: заттық, жеке тұлғалық, уақыттық, кеңістіктік, мәтіндік, заттық мәтіндік, кеңістіктік мәтіндік т.б.

Жеке тұлвалық дейксис I, II жақ есімдіктері арқылы көрініс береді де, сөйлеу ситуациясындағы сөйлеуші мен тыңдаушы сілтейді. Ал III жақ есімдігі бөгде тұлғаны көрсетеді.

Заттық дейксис коммуникативтік актідегі барынша маңызды заттарды, оқиғаларды, объектілерді көрсетеді. Заттық дейксис сілтеу есімдіктері арқылы көрініс береді.

Кеңістіктік дейксис сөйлеуші мен тыңдаушы тұлғаларынан қашықтық, көріну-көрінбеу, қол жетімділік қол жетімсіздік бойынша заттарды сілтеп көрсетеді де, көбіне сілтеу есімдіктерімен беріледі.

Уақыттық дейксис сөйлеу сәтіне қатысты уақыт аралықтарын көрсетеді және бұл да сілтеу есімдіктері арқылы көрінеді.

Мәтіндік дейксис коммуникативтік актідегі мәтіннің үзінділерін түгелімен көрсете алады.

Заттық мәтіндік дейксис мәтіннің элементтерін теңестіруде, оларды тура сілтеуде көрініс берсе, кеңістіктік мәтіндік дейксис мәтіндер арасындағы кеңістіктік қатынасты тура сілтеуде байқалады.

Дейксис туралы айтқанда, бұл, сол, осы, мұнда, онда, сонда, осында, міне, әне сияқты сілтеу есімдіктері алғаш тілге оралады, сондай-ақ, олардың осыдан, содан, мұнан, бұдан т.б. тәрізді семантикалық туындылары да еске түседі.

Осы сілтеу ұғымымен байланысты тағы бір байланыс құралы - анафоралық есімдіктер. "Анафора" (айтылғанды сілтеу) болып табылады. Оны біз "айтылғанды сілтеу" деп шартты түрде атадық. Бір сөздің мағынасында екінші бір сөзге деген сілтеуі бар болатын тілдік сөйлесімдердің қарым-қатынасы анафоралық (айтылғанды сілтеу) қатынас болып табылады.

Анафоралық (айтылғанды сілтеу) және дейксистік (тура сілтеу) контекстердің байланысы төл және автор сөздерінің бірігуінде анық көрінеді, төл сөзде дейксис көрінсе, автор сөзі дейксистік (тура сілтеу) контексте таратушы болады. Мұндай жағдайда сілтеу дейксистік (тура сілтеу) те, анафоралық (айтылғанды сілтеу) та бола алады.

Қорытынды. Есімдіктердің синтаксистік жүйедегі қызметін олардың сілтеу функциясы белгілейді. Функциональды грамматика аясында белгілі бір семантикалық қызметті атқару, яғни сілтеу қызметін (жақтық, темпоральды қатынастарды белгілеу қызметін) іске асыру үшін жіктеу және сілтеу есімдіктерінің өз антецеденттерімен өзара әрекет жасауы анықталады. Темпоральдылықты көрсететін құрал ретінде сілтеу есімдіктерін атасақ, персональдылықтың, яғни дербестіліктің құралы ретінде жіктеу есімдіктерін атай аламыз.

Сілтеудің түрлі бірліктері қазіргі лингвистикада дейксис пен эгоцентризм, анафора теорияларының негізінде қарастырылуда. Ал осы сілтеу ұғымы есімдіктердің ішінде, әсіресе, жіктеу және сілтеу есімдіктеріне тән болып келеді. Сондықтан да жіктеу, сілтеу есімдіктерінің мәтінді байланыстырудағы қолданыстары мен қызметін зерделеп, олардың мәнін анықтаудың маңызы өте зор болмақ.

Жіктеу есімдіктерінің ішінде I, II жақ есімдіктері анафоралық қызметтен гөрі дейксистік қолданысқа бейім болса, III жақ жіктеу есімдігі анафоралық қолданыста көп жұмсалады.

Сілтеу есімдіктері анафоралық (айтылғанды сілтеу) қолданыста кеңінен жұмсалып, мәтін, сөйлем элементтерін байланыстырады және де мәтіндегі керексіз қайталауларды ауыстырады. Бұл қызметінде олар өзіндік анафоралық (айтылғанды сілтеу) та, катафоралық (алдын алушы) та қолданыстарда жұмсалады. Есімдіктердің бұл қызметі мәтін синтаксисінде кеңінен орын алады.

Катафоралық (алдын алушы) сілтеулер көбінесе бір нәрсе жайын ұзақ түсіндіруде, көрсетуде жұмсалады. Автор өзі айтатын, өзі орындатқысы келетін нәрселерге тыңдаушылардың назар салып қарау қажеттігін ескерткісі келгенде көбіне сілтеу есімдіктерін катафоралы қолданады.

Пайдаланылван ддебиеттер тізімі:

1 Сыздықұва Р. Қазақ тіліндегі ескіліктер мен жаңалықтар. - Алматы: Арыс, 2009. -182 б.-кітап

2 Смадұлова Г. Мәтін лингвистикасы. - Алматы: Қазақ университеті, 2002. - 112 б.-кітап

3 Ахметова М. Мәтін лингвистикасы. - Орал: «Авартушы», 2008. - 148 б. -кітап

4 Арутюнова Н. Язык о языке. - Москва: Наука, 2010. - 163 с.-книга

5 Кравченко А. Вопросы теории указательности: эгоиентричность, дейктичность, индексальность. Иркутск: Иркутский университет, 1992. - 133 с.-книга

6 Бейсембаева К.А. Невербальные компоненты коммуникации в казахском языке // КД. - Алматы, 2012. кiman

7 Сарыбаев Ш. Қазақ тіл білімі мәселелері. - Алматы: Арыс, 2000. - 227 б. -кітап

8 Әмір Р. Құрмалас сөйлем жүйесі. - Алматы: Қазақ университеті, 2014. - 275 б. -кітап

9 Құрманова Н. Қазіргі қазақ тіліндегі сөз тіркестерінің жүйелік құрылымыының сипаты, оны талдау жолдары. - Алматы: Ана тілі, 2011. - 173 б. -кітап

References:

1 Syzdyqova R. Qazaq tılındegl eskllıkter men jañalyqtar. - Almaty: Arys, 2009. -182 b.-kıtap

2 Smağūlova G. Mätın lingvistikasy. - Almaty: Qazaq universitetı, 2002. - 112 b.-kıtap

3 Ahmetova M. Mätın lingvistikasy. - Oral: «Ağartuşy», 2008. - 148 b. -kıtap

4 Arutünova N. Iazyk o iazyke. - Moskva: Nauka, 2010. - 163 s.-kniga 
5 Kravchenko A. Voprosy teorii ukazatelnosti: egosentrichnöst, deiktichnöst, indeksälnöst. - Irkutsk: Irkutski universitet, 1992. - 133 s.-kniga

6 Beisembaeva K.A. Neverbälnye komponenty komunikasii v kazahskom iazyke // KD. - Almaty, 2012. -kitap

7 Sarybaev Ş. Qazaq tıl bilımı mäselelert. - Almaty: Arys, 2000. - 227 b. -kitap

8 Ämir R. Qürmalas söilem jüiess. - Almaty: Qazaq universitet, 2014. - 275 b. -kitap

9 Qürmanova N. Qazırgı qazaq tılındegı söz tırkesterınıñ jüielık qürylymynyñ sipaty, ony taldau joldary. - Almaty: Ana till, 2011. - 173 b. -kitap

МРНТИ 13.00.02

https://doi.org/10.51889/2021-1.1728-7804.24

Мусатаева М.Ш., ${ }^{1}$ Дюсенова Д.С. ${ }^{2}$

${ }^{1,2}$ Казахский национальный педагогический университет имени Абая, Алматы, Казахстан

\section{РОЛЬ РУССКОГО ЯЗЫКА КАК УЧЕБНОГО ПРЕДМЕТА В ФОРМИРОВАНИИ КЛЮЧЕВЫХ КОМПЕТЕНЦИЙ ОБУЧАЮЩИХСЯ}

Аннотация
Во все времена в лингводидактике актуальность представляло формирование гармонично развитой личности, обладающей всеми ключевыми компетенциями. Реализация этой сверхзадачи в той или иной мере осуществлялась сообразно времени. Смена образовательных парадигм показала, что ценность ключевых компетенций является константой в дидактике. И в настоящее время компетентностный подход в образовании остается главенствующим. Несмотря на то, что компетентностному подходу в целом посвящено большое количество литературы, недостаточно освещенным остается вопрос о путях формирования ключевых компетенций в частных методиках. Каждый предмет располагает своими потенциальными возможностями, которые должны быть описаны. Как известно, учебный материал, представленный в Типовых учебных программах, нуждается в научном обосновании. В связи с этим в рамках данной статьи нами делается попытка рассмотреть пути формирования ключевых компетенций учащихся на уроках русского языка в казахских школах.

Ключевые слова: лингводидактика, компетентностный подход, компетенция, компетентность, мотивация, личностно-ориентированный подход, эвристический подход, ключевые компетенции, интерактивность, мобильное образование

$$
\begin{gathered}
\text { Мусатаева М.Ш., }{ }^{1} \text { Дюсенова Д.С. }{ }^{2} \\
{ }_{1,2} \text { Абай атындагы Қазақ ұлттық педагогикалық университеті, } \\
\text { Алматы, Қазақстан } \\
\text { СТУДЕНТТЕРДІН НЕГІЗГІ ҚҰЗЫРЕТТІЛІГІН ҚАЛЫПТАСТЫРУДА } \\
\text { ОРЫС ТІЛІНІН ОҚУ ПӘНІ РЕТІНДЕГІ РӨЛІ }
\end{gathered}
$$

\section{СТУДЕНТТЕРДІН НЕГІЗГІ ҚҰЗЫРЕТТІЛІГІН ҚАЛЫПТАСТЫРУДА ОРЫС ТІЛІНІН ОҚУ ПӘНІ РЕТІНДЕГІ РӨЛІ}

\section{Андатпа}

Әр заманда лингводидактикада барлық негізгі құзыреттерге ие, үйлесімді дамыған тұлғаны қалыптастыру өзекті болды. Бұл маңызды міндет жүзеге әртүрлі деңгейде заманға сай асырылды. Білім беру парадигмаларының өзгеруі басты құзыреттіліктердің мәні дидактикада тұрақты екенін көрсетті. Қазіргі уақытта да білім беруде құзыреттілік тәсіл басым. Жалпы компетенцияларға арналған әдебиеттің молдығына қарамастан, жеке әдістерде негізгі құзыреттіліктерді қалыптастыру жолдары мәселесі жеткіліксіз жарықтандырылғанекені айқын. Әр пәннің өзіндік әлеуеті бар екені ақиқат, сондықтан оны сипатталуы қажет. Типтік оқу бағдарламаларында берілген оқу материалдары ғылыми тұрғыдан сипатталмаған. Осыған орай, біз осы мақала аясында қазақ мектептерінде оқылатын орыс тілі сабағында оқушылардың негізгі құзыреттіліктерін қалыптастыру жолдарын қарастыруға тырысамыз.

Түйін сөздер: лингводидактика, уәжділік, тұлғаға бағытталған әдіс, эвристикалық тәсіл, негізгі құзыреттілік, интербелсенділік, мобильді білім

$$
\begin{gathered}
\text { Mussatayeva M., }{ }^{1} \text { Dyussenova } D .^{2} \\
{ }^{1,2} \text { Abai Kazakh National Pedagogical University, } \\
\text { Almaty, Kazakhstan }
\end{gathered}
$$

